\title{
Defining Problems and Solutions of Education for Frontier, Outermost, and Least Developed Regions Program in Indonesia
}

\author{
Sri Marmoah, Universitas Sebelas Maret, marmuah@staff.uns.ac.id, ORCID: 0000-0003-3485-1551 \\ Aurora Adina Colomeischi, Stefan cel Mare University of Suceava, adina.colomeischi@usm.ro, ORCID: \\ 0000-0002-9663-8302
}

Diana Sinziana Duca, Stefan cel Mare University of Suceava, diana.duca@usm.ro, ORCID: 0000-00030250-4811

\begin{abstract}
This research aims to analyze the problem, solutions, and impact of education for Frontier, Outermost, and Least Developed Regions (FOLDR) in Indonesia. The methodological research used was qualitative. The research had been done in FOLDR teachers followed by Teacher Professional Education (TPE) training program in Universitas Sebelas Maret with a total of 31 teachers working in seven places. Data collection in this study used the method of observation, interviews, and documentation. The data analysis used was inductive technique method through reducing the data, presenting the data, and conclusion arrangement. The conclusion of this research were: there are some problems with the implementation of education if they were referred to 7M (Man, Money, Method, Machine, Material, Market, Minute); the solutions suggested in this study related to the problems defined were submitting the construction of a study room building to the local office, holding a donation, conducting a competence training for teachers, and arranging additional lessons or classes, and enrolling the number of teacher to the local office; and FOLDR program has a positive impact on the FOLDR area.
\end{abstract}

Keywords: FOLDR Program, Problems, Solutions

Received: 03.02.2019 Accepted: 14.07.2020 Published: 15.01.2021

\section{INTRODUCTION}

Indonesia has an area of 5,193,250 $\mathrm{km}^{2}$ consisted of thousands island with 122 regions including the area of FOLDR (Frontier, Outermost, and Least Developed Region) category. The educational problems arisen in the FOLDR area including the shortage of teaching staff, uneven facilities, unbalanced distribution, under qualification, low competencies, low interest in learning, and mismatched of teaching background (Yustina \& Dahnilsyah, 2015; Mulkeen \& Chen, 2008; Flora et al., 2003; Singh et al., 2010). Meanwhile, Campbell and Yates (2011) reported that one of the unique attitudes of teachers in remote areas is the metro-centric attitude. The metro-centric attitude is always oriented towards living in urban areas and refusing to live in a remote area (Nagy \& Robinson, 2013). However, this phenomenon is not generally accepted because Beck and Shoffstall (2005) report otherwise that elementary school students from rural Illinois in the United States have higher learning achievement than urban students in reading and science subjects. Meanwhile, Reeves and Bylund (2005) prove that there are no significant differences in academic achievement of rural and urban students. So that education research in rural areas is still interesting to study especially because of its uniqueness in different regions and cultural characteristics.

Some regions in the European Union countries are increasing extremes weather for climate change. This makes educational learning reform learning devices (Hakhverdian et al., 2013). In addition, the outermost region in North America is also developing. Several things were done to make changes, such as this experiment because there were still some areas that needed education approval (Fitzgerald \& Lenhart, 2015). Research conducted by the Chartered Institute of Management Accountants (CIMA) shows that one-third (31\%) of companies need more than two months to fill a junior role, and at the appointment of three-quarters (75\%) of relationships in the UK need significant assistance. This is higher than other places in Europe (47.1\%). Some schools in the UK have a system of work with each other so that schools do not 
provide the subjects needed to work in companies. Next, there is an increase between employers and educators. They increase it through discussion and practical experience in class. The Organization for Economic Cooperation and Development (OECD) found that children 16 to 24 years of age had literacy and numeracy skills level that were below their grandparents' generation skills (OECD, 2015). The fact has to be related education process.

Cuervo (2012) highlights the attractiveness and retention of early career teachers to rural areas. He stated that it was a form of concern for rural communities, but it was part of a broader agenda. Karaomerlioglu (1998) tells that Turkey has a history of efforts to realize education in rural areas. This lasted from 1937 to the mid-1940s. The established institutions have great hopes to develop the countryside, such as solving problems of poverty and underdevelopment of science, creating intellectual farmers, increasing agricultural productivity, and helping to spread the Kemalist revolution in the countryside. In rural areas, insights on education and the economy have not been given special attention so conditions have worsened. However, with the support of farmers, acknowledgment that education is a tool that can improve the quality of life of villagers.

Education in Turkey is also almost the same as education in Indonesia, especially in terms of primary and secondary education. Unfortunately, secondary education in rural areas of Turkey is not optimal because many students are not yet skilled in managerial matters. They are only equipped to replace the bureaucracy and are recruited to work in their own villages. It can be said that village education in Turkey still bases general knowledge rather than practical needs in the workplace, so there are many allegations that village institutions ignore student development (Altinyelken, 2011).

The history of practical education in Turkey has a beneficial effect in the future. The problem of education is corrected by adding many continuing education programs. Green (2015) argues that sustainability in this context refers to how, why, and what happens in the present to have impacts on the future. On the other hand, Goodwin and Kosnik (2013) described that undoubtedly, we need teachers who are diverse not just in how they look, where they come from, the language they speak, and the histories they embody, but in how they think, how they interact with other(s), and how they are able to embrace a world where citizenship is differentiated and is not simply legal or minimal, but active and transformative genuinely. However, Halsey (2011) explained that teachers in a rural area can have a direct impact on determining long-term sustainability of rural communities as schools are central to the life and viability of rural towns, a view often expressed. To support the arguments, McManus et al. (2012) addressed the perceived inequalities of rural schooling from a social justice perspective, arguing that the sustainability of rural communities was a national and global issue. Also, Cochran-Smith et al. (2009) claim that the most important goals of teacher education programs are: social responsibility, social change, and social justice, and those are the goals that should be taken as frameworks or programs.

The government has created a draft of policy for the recruitment of civil servant teachers, with special methods so that professional teachers can be obtained and are ready to serve throughout the Republic of Indonesia region to educate and to embrace the nation's children. The program is known as Bachelor of Teaching Program graduates sent to teach in FOLDR (Frontier, Outermost, and Least Developed Regions) and TPE (Teacher Professional Education) training program. Buchory (2012) said that TPE program is a new program because it was designed operationally based on Minister of Education and Culture Number 8 of 2009. In the National Education Ministerial Regulation, it was stated that TPE is an educational program organized to prepare S1 and S1/S1 graduates DIV is non-educated who has the talent and interest in becoming a teacher to master teacher competency as a whole in accordance with national education standards, so that they can obtain professional educator certificates in early childhood education, basic education, and secondary education. The aim of the TPE program is to produce prospective teachers who have the competence in planning, implementing, and assessing learning; to follow up on the results of the assessment by guiding and training students; and to be able to conduct research and develop professionalism on an ongoing basis (Minister of Education and Culture No. 8, 2009, article 2). 
The program of FOLDR is an educator service program to participate in the acceleration of education development in the FOLDR area for one year as the preparation of professional educators which will be continued with the TPE program. The program of FOLDR, scholars is not only qualified in education but socially, they learn to be strong, adaptive, change their culture to be better. In addition to progress in community life, the presence of FOLDR also captures information about portraits of education in the FOLDR category, both man and tool. Recipients of the FOLDR program are entitled to continue the professional teacher education program for free.

They will be guided in more depth on how to become professional teachers. After the completion of the teacher professional education, the teacher is expected to return to teach in the FOLDR area again to further develop the previous school for several years. This process is carried out on an ongoing basis with several other FOLDR program registrants. The Scholars teach in FOLDR area program aims to assist FOLDR regions in overcoming educational problems, especially the lack of educators, to provide experience of devotion to undergraduate education so that professional attitudes and skills in solving educational problems are formed, foster an attitude of love for the country and be responsible for the progress of the nation, the teachers who works in the FOLDR area and prepares prospective professional educators before joining TPE program.

The results of this study are expected to provide support to teachers to become more professional. Thus, the results will have a direct impact on society on an ongoing basis. So far education research in remote areas with cases in Indonesia has not been widely reported. This research is expected to be the initiation of studies in that direction. The formulation of the problem in this study is "What are the analysis results on the FOLDR teaching program in dealing with educational problems and solutions in the FOLDR area (Case Study of FOLDR teachers who take part in TPE program at the Universitas Sebelas Maret)?"

Based on the former studies from other researchers and pilot study conducted in the beginning of this study, the questions researches were defined, namely:

1. What are the problems found on the education implementation of FOLDR (Frontier, Outermost, and Least Developed Regions) program?

2. What are the solutions to the FOLDR (Frontier, Outermost, and Least Developed Regions) program related educational problem found?

3. What are the impacts of implementing FOLDR (Frontier, Outermost, and Least Developed Regions) program in Indonesia?

\section{METHODS}

The approach used by researchers in this study was qualitative approach as methodological research. A qualitative approach is used because the researcher wants to analyze more deeply the cases that are the focus of this study. The aim of this study is to analyze the problems, solutions, and impacts of education through Bachelor of Teaching Program graduates sent to teach in FOLDR area. The discovery of research subjects was using purposive sampling technique, namely the technique of determining the sample with certain considerations (Sugiyono, 2013). This technique is used because researchers want to focus this research in accordance with the objectives and research subjects.

\section{Participants}

The subjects in this study were the FOLDR graduates who were taking TPE program in Universitas Sebelas Maret. The subjects in this study were 31 FOLDR teachers who have sub served to teach in Asmad (Papua), Parigi Moutong (Central Sulawesi), Malacca (East Nusa Tenggara), South Nias (South Sumatra), Melawi (West Kalimantan), West Southeast Maluku (Maluku), and West Sulawesi. This subject was chosen because Universitas Sebelas Maret was one of the universities chosen by the Government within legal documentation in both structural and infrastructural facilities to conduct TPE program in both pre-service area and the office area. 


\section{Data Collection and Analysis}

Data collection used in this study was the method of observation, interviews, and documentation. The type of data used in the research process was divided into two groups, namely primary data and secondary data. Primary data is collected through several methods, namely observations, interviews, and documentation. The primary data in this study is information about educational problems in the FOLDR program. Observations were made by observing learning process in the FOLDR area. Interviews were conducted with teachers who were being teachers in the FOLDR area and joining FOLDR program placed by the government of Indonesia. Interviews were conducted to each subject taken in this study who gave their consent to give the information related to the implementation of FOLDR program in rural area of Indonesia. Documentation method was done by analyzing the archives and documents at schools.

These three techniques were chosen because to strengthen the data needed by researchers. Secondary data is collected by reading the results of research or documentation about the history or background of the schools as the places of research. Data analysis in this study has two types of analysis, namely analyzing to determine the data validity and conducting data analysis through interpretation of the overall data. The data analysis used was inductive technique method through reducing the data, presenting the data, and conclusion arrangement.

\section{Data Validation}

Triangulation method was used to certain that this research is valid through several data collecting. Triangulation methods used were technical triangulation and source triangulation. Triangulation techniques are carried out by using various data collection techniques to obtain consistency from the sources of observations, interviews, and documentation method of collecting data. The source triangulation is done by collecting data from various sources, namely several students in Papua, Kalimantan, Sumatra, Sulawesi, Maluku, and East Nusa Tenggara. Before the researcher validates the data, the researcher arranges the instrument first.

These instruments include interview guidelines, observation sheets, and documentation sheets. The instruments that have been made are tested in a construct and content manner to expert assessors or expert judgment. The instrument can be used for research if it has been declared feasible by expert judgment. The instrument was not tested because it was felt to be sufficient to represent the needs of the construct and content to collect research data.

\section{RESULTS}

\section{Defining FOLDR Educational Problems Referred to 7M Characteristics}

The FOLDR program as one of the Indonesian Advanced Learning and Educating Programs is aimed at Education Graduates or those who have not yet served as civil servant teachers, to be assigned for one year in the FOLDR area. The FOLDR program is intended to help strengthening teacher shortages, while at the same time preparing professional teacher candidates who are strong, independent, and have a caring attitude towards others, and also to have the spirit to educate the national children. The problem in this study refers to $7 \mathrm{M}$ (Man, Money, Method, Machine, Material, Market, and Minute) of educational management. First, man aspect covers human resources in schools. Second, money aspect covers everything related to school management and educational funding. Third, method aspect covers learning methods and innovations. Fourth, machine aspect discusses technology and learning media. Fifth, material aspect discusses material and sum learning. Sixth, market aspect discusses school marketing strategies. Seventh, minute aspects discuss management of study time.

Table 1 indicates that the majority of respondents have some problems with human resources. The first problem is about the teachers. The number of teachers is still lacking and it leads to the shortage of teaching staff, unbalanced distribution, so in seven regions there are still many honorary teachers. Besides that, the lack of quality teachers, some teachers are already undergraduates and there are still high school graduates who are not having the requirements 
for the educational standard of teachers. The other problem is the lack of technology, for example, all teachers and principals in the seven regions area cannot use computers. The second problem is about the students. Many students who have not been able to read, write, and count. Besides that, the problems have also been found in students such as lack of quality in students, lack of skills mastery, lack of interest in learning, lack of discipline, lack of absorption toward the material, and difficulties in adapting with various challenges. From seven regions, there are many students who have been dropped out of school. The third problem is about the supporting of parents. The parents' concern for education is still lacking in supporting their children for learning. For example, in the Papua region, some parents make a living as eagerness seekers so that at certain times they cluster away from the forest and bring their children who are still in school.

Table 1. Man problems (human resource management)

\begin{tabular}{|c|c|}
\hline Participant & FOLDR Educational Problems Obtained \\
\hline Papua & $\begin{array}{l}\text { Papua lacks the number of teachers in the Asmat district on average one school only } \\
\text { has two teachers and one school principal. Students often come with their parents to } \\
\text { the forest so they often don't attend school. Parents make a living as eagerness seekers } \\
\text { so that at certain times they cluster away from the forest and bring their children who } \\
\text { are still in school. Conditions for many students who have not been able to read, write, } \\
\text { and count. The ability to master the Indonesian language is very minimal, even the low- } \\
\text { class level cannot speak Indonesian. }\end{array}$ \\
\hline $\begin{array}{l}\text { Southeast } \\
\text { Sulawesi }\end{array}$ & $\begin{array}{l}\text { In terms of quantity and quality, teachers are inadequate. Some teachers are already } \\
\text { undergraduates and there are still high school graduates. From the student side, the } \\
\text { quality of students is still relatively slow compared to regular schools. }\end{array}$ \\
\hline West Sulawesi & $\begin{array}{l}\text { The number of teachers is still lacking, there are still many honorary teachers, and } \\
\text { many high school graduates are not in accordance with teacher qualifications. The } \\
\text { parents' concern for education is still lacking in supporting school programs. }\end{array}$ \\
\hline $\begin{array}{l}\text { East Nusa } \\
\text { Tenggara }\end{array}$ & $\begin{array}{l}\text { The teacher's human resources are still low. The number of civil servant teachers is } \\
\text { only three including the principal. Meanwhile, the other honorary staff who cannot go } \\
\text { to school every day to teach. Students' learning motivation is still lacking. In the upper } \\
\text { class, there are still students who have not been able to read, write, and count. Some } \\
\text { students are identified to have learning difficulties but there was no specific treatment } \\
\text { to overcome each problem regarding students' problems. }\end{array}$ \\
\hline & $\begin{array}{l}\text { The number of teachers where the subject works are only four people. One is the } \\
\text { principal, two teachers are S1 qualified, and one teacher in high school qualified. } \\
\text { Students' enthusiasm to attend school is good but it is not accompanied by enthusiasm } \\
\text { in learning. The education level of the surrounding community is still low and many } \\
\text { teenagers drop out of school in order to find job of helping families. }\end{array}$ \\
\hline Maluku & $\begin{array}{l}\text { All teachers and principals in the area where the subject teaches cannot use computers. } \\
\text { Teachers are still lacking, there are only two civil servant teachers and many honorary } \\
\text { teachers. Students are identified to have low literacy, science, mathematics, and } \\
\text { language skills. Also, students' enthusiasm and lack of interest in learning lead to the } \\
\text { lack of discipline, the lack of absorption of students' achievements towards the } \\
\text { materials, and the lack of personal hygiene. Meanwhile, dropout rates are still high. }\end{array}$ \\
\hline North Sumatra & $\begin{array}{l}\text { Teachers in Nias are considered as important people after the Pastor. There are already } \\
\text { many teachers, even in remote areas. But, teachers' educational qualifications are still } \\
\text { low. Many students are interested in studying and being diligent at school. }\end{array}$ \\
\hline
\end{tabular}

Then, they are also asked a question about how their money problem is, especially how the funding management is. Their responses are summarized in Table 2. As shown in Table 2, it indicates that from seven regions there is no problem with funding management. There is some information about the funding. First, school funding is all free for students because the economy of the community is classified as a lower economy, mostly working as garden farmers. Second, most students also have received the ISC cards and OAF from the government. The third, the existence of school operational assistance funds or BOS as capital is the center in school funding. 
The funding is channeled to buy school equipment, tools, learning media, books as learning resources, and extracurricular activities that support learning.

Table 2. Money problems (financial management)

\begin{tabular}{|c|c|}
\hline Participant & FOLDR Educational Problems Obtained \\
\hline Papua & $\begin{array}{l}\text { School tuition is all free for students. There are no levies from the school because the } \\
\text { average parent of many students is unable to pay the tuition. }\end{array}$ \\
\hline $\begin{array}{l}\text { Southeast } \\
\text { Sulawesi }\end{array}$ & $\begin{array}{l}\text { There is no management of school funding because all students are free of charge. This } \\
\text { is because the economy of the community is classified as a lower economy, mostly } \\
\text { working as garden farmers. Funds managed by schools only come from Operational } \\
\text { Assistance Funding (OAF). }\end{array}$ \\
\hline West Sulawesi & $\begin{array}{l}\text { There is no management of school funding because all students are free of charge. This } \\
\text { is because the economy of the community is classified as a lower economy, mostly } \\
\text { working as garden farmers. Funds managed by schools only come from School OAF. }\end{array}$ \\
\hline $\begin{array}{l}\text { East Nusa } \\
\text { Tenggara }\end{array}$ & $\begin{array}{l}\text { Students are free of charge or free to go to school within the existence of school } \\
\text { operational assistance funds as capital in school funding. }\end{array}$ \\
\hline \multicolumn{2}{|c|}{$\begin{array}{r}\text { West Kalimantan Stude } \\
\text { that t } \\
\text { for th }\end{array}$} \\
\hline Maluku & $\begin{array}{l}\text { Free school fees are happened as they are covered by OAF. Most students also have } \\
\text { received the Indonesia Smart Card (ISC) from the government. Funding in schools } \\
\text { doesn't lead to major problems or any significant problem because budgeting for } \\
\text { schools is arranged together so that there is budget transparency for all of school staff } \\
\text { in Maluku. }\end{array}$ \\
\hline North Sumatra & $\begin{array}{l}\text { The funding that goes to the school where the subject teaches comes from OAF. The } \\
\text { funding is channeled to buy school equipment, tools, learning media, books as learning } \\
\text { resources, and extracurricular activities that support learning process. }\end{array}$ \\
\hline
\end{tabular}

The subjects was also then asked questions about method problem, especially how the management of methods. Their responses are summarized in Table 3. Based on the FOLDR graduates perceptions who were taking TPE, their perception of the management of method are shown in Table 3. It is clearly seen that some of the elementary school teachers in seven regions state that their method in teaching learning process used in managing education in the FOLDR area still feels stagnant. It is because in learning activities, most teachers still use conventional methods. Learning process is mostly done by dictating, lecturing, and giving assignments. There has been no innovation in learning material. Meanwhile, the other problem is that the teacher does not know a variety of innovative learning method. The use of learning media has not been done yet because the teachers have never participated in the Teachers Working Groups program. They domicile apart and the distance between the unit of education district from the education office are quite far.

Table 3. Method problem (management of methods, learning innovations)

\begin{tabular}{cl}
\hline Participant & \multicolumn{1}{c}{ FOLDR Educational Problems Obtained } \\
\hline Papua & $\begin{array}{l}\text { The lack of teachers competency there has an impact on the lack of development of } \\
\text { learning methods and learning innovations. The most important thing in Asmat ethnic } \\
\text { group is that children can read, write, and count. During the teaching and learning process, } \\
\text { the teacher only lectures without using media or learning methods. The learning process } \\
\text { tends to be monotonous and encourages students to only memorize the lesson. The } \\
\text { method uses lectures because there is no media to supports the class. }\end{array}$ \\
$\begin{array}{c}\text { Southeast } \\
\text { Sulawesi }\end{array}$ & $\begin{array}{l}\text { In learning activities, most teachers still use conventional methods and learning is mostly } \\
\text { done by dictating, lecturing, giving assignments, and there has been no innovation in } \\
\text { learning material. }\end{array}$
\end{tabular}


Table 3. Method problem (management of methods, learning innovations) (Continued)

\begin{tabular}{|c|c|}
\hline Participant & FOLDR Educational Problems Obtained \\
\hline \multicolumn{2}{|c|}{$\begin{array}{c}\text { West Sulawesi In learning activities, most teachers still use conventional methods, lectures, } \\
\text { memorization, and dictation. }\end{array}$} \\
\hline $\begin{array}{l}\text { East Nusa } \\
\text { Tenggara }\end{array}$ & $\begin{array}{l}\text { The method used in managing education in the FOLDR area still feels very conventional } \\
\text { because it only relies on the teachers as the main center in education. The processes of } \\
\text { learning are fewer involving parents, the community or the student environment. In } \\
\text { addition, knowledge related to limited learning methods is one of the main factors, the }\end{array}$ \\
\hline $\begin{array}{l}\text { West } \\
\text { Kalimantan }\end{array}$ & $\begin{array}{l}\text { The subjects state that they find it difficult to innovate in the FOLDR area. Limited } \\
\text { resources such as the absence of electricity and communication network signals are one of } \\
\text { the causes. The location of the hamlet was isolated in the middle of the forest far from } \\
\text { urban areas and access to the district was very difficult with a PP fee of five hundred }\end{array}$ \\
\hline Maluku & $\begin{array}{l}\text { The methods used by teachers in schools generally only are direct lecturing with questions } \\
\text { and answers method only. The method used is still using conventional method and } \\
\text { learning process is still teacher centered. }\end{array}$ \\
\hline $\begin{array}{l}\text { North } \\
\text { Sumatra }\end{array}$ & $\begin{array}{l}\text { Learning process in North Sumatra method still uses lecture and assignment method. The } \\
\text { problem is that the teacher does not know a variety of innovative learning methods, using } \\
\text { learning media because the teachers have never participated in the KKG apart from the } \\
\text { distance between the Unit of education district and the education office. }\end{array}$ \\
\hline
\end{tabular}

Table 4 presents data from the FOLDR graduate's perception related to machine problems that were taking TPE about media management and learning technology. It is clearly seen that all school from the seven regions have machine problems specifically in media and learning technology. They admit that their schools cannot use media such as laptops and projectors because there is no electricity. On the other hand, they have not been able to use internet-based media because of the limitations of signals yet not affordable source. Schools rely on diesel as a source of electricity. Interestingly, two schools in West of Kalimantan and West Sulawesi, the use of technology at school has begun to exist. Every school has at least one computer, one laptop, and one printer. However, the utilization is still not optimal, because many teachers are still stuttering technology as they have been recognized the devices not for a long time. The media is not properly utilized and is just being put in the warehouse. This finding shows that a lot of media is damaged because it is not used as operational device at school. Teachers and school staff need to be educated to utilize the media as learning tools due to the process of teaching and learning.

Table 4. Machine problems (media management, learning technology)

\begin{tabular}{cl}
\hline Particpant & \multicolumn{1}{c}{ FOLDR Educational Problems Obtained } \\
\hline Papua & $\begin{array}{l}\text { Technologies such as computers and printers are not yet available because there is no } \\
\text { electricity source. Most schools in the Asmat ethnic group have not used technology. } \\
\text { There is no electricity, signals, and the access is far from the city. }\end{array}$ \\
$\begin{array}{c}\text { Southeast } \\
\text { Sulawesi }\end{array}$ & $\begin{array}{l}\text { School staff cannot use media such as laptops and projectors because there is no } \\
\text { electricity. It has not been able to use internet-based media because of the mobile } \\
\text { phone signals limitation that are not affordable for school staffs. Schools rely on diesel }\end{array}$ \\
as a source of electricity during the gymnastics agenda every Friday. \\
West Sulawesi \\
The use of technology has begun to exist. Every school has at least one computer, one \\
laptop, and one printer. However, the utilization is still not optimal, because many \\
teachers are still stuttering from technology applied in the city.
\end{tabular}


Table 4. Machine problems (media management, learning technology) (Continued)

\begin{tabular}{cl}
\hline Particpant & \multicolumn{1}{c}{ FOLDR Educational Problems Obtained } \\
\hline West Kalimantan The learning media in the school where the students was assigned was quite adequate. \\
Schools receive assistance from the education office. However, the media is not \\
properly utilized and is just put in the warehouse, so that a lot of media is damaged \\
The use of media, machinery, and technology is still lacking because there is no electricity \\
network to support this. Village electricity still relies on a generator set that is on for 4 \\
hours from 6:00 to 10:00 p.m., even if oil (diesel) is sufficient. \\
North Sumatra
\end{tabular}

In addition to the problems of human resources, methods, funding, and machinery, other findings faced by schools in the FOLDR area are school materials. The management of school materials is one aspect that will be explored further in this study. Table 5 presents data from the FOLDR graduate's perception of the management of learning materials.

Table 5. Material problems (management of learning materials)

\begin{tabular}{|c|c|}
\hline Participant & FOLDR Educational Problems Obtained \\
\hline Papua & $\begin{array}{l}\text { Teaching materials used in most areas in the Asmat ethnic group district still use } \\
\text { competence-based curriculum. The applied resource of teaching is using curriculum- } \\
\text { based books. The materials used are only teacher knowledge and makeshift textbooks. }\end{array}$ \\
\hline $\begin{array}{l}\text { Southeast } \\
\text { Sulawesi }\end{array}$ & $\begin{array}{l}\text { Learning material has been equated with regular schools using competence-based } \\
\text { curriculum. But, there are some schools that have implemented the } 2013 \text { curriculum, } \\
\text { but it is still in the experimental stage of implementation. }\end{array}$ \\
\hline West Sulawesi & $\begin{array}{l}\text { The teaching material used in the school where the subject teaches is in charge still } \\
\text { uses book from competence-based curriculum. The books provided are not preserved } \\
\text { to the number of students so many students are still in pairs and took turns using }\end{array}$ \\
\hline East Nusa & The teaching materials used in the school where the subject teaches still uses book \\
\hline Tenggara & $\begin{array}{l}\text { from competence-based curriculum. The books provided are not preserved to the } \\
\text { number of students so many students were still in pairs and took turns using books. }\end{array}$ \\
\hline & $\begin{array}{l}\text { The existing sourcebook is still very limited and not updated. To find the latest sources } \\
\text { of learning materials is quite difficult as there are also obstacles due to the absence of } \\
\text { communication or internet network signals. }\end{array}$ \\
\hline Maluku & $\begin{array}{l}\text { The learning method used is still using lectures, because of the limited facilities and } \\
\text { unavailable infrastructure. Less use of available learning media. }\end{array}$ \\
\hline North Sumatra & $\begin{array}{l}\text { Teaching materials used are not in accordance with the curriculum. There are only } \\
2013 \text { curriculum books, but the teachers do not understand how to use the book, so the } \\
\text { material taught is often not appropriate. }\end{array}$ \\
\hline
\end{tabular}

Based on students who have taken TPE program and joined FOLDR teaching program, their perception of the material problems are shown in Table 5, it is clearly seen that learning material has been equated with regular schools using competence-based curriculum. However, two schools in North Sumatra and Central Sulawesi have implemented the 2013 curriculum, but it is still in the experimental stage. Furthermore, several existing sourcebooks is still very limited and not updated. Books available at school come from old or conventional books with a long year of publication. There are obstacles due to the absence of communication or internet network signals to find the latest sources of learning materials, so the learning process is not optimal. Moreover, the books provided in school were preserved according to the number of students so many students were still in pairs.

Furthermore, another problem that is no less important is the management of schools, especially how teachers market their schools to the community. The hope is that the community will be interested in participating to empathize to send their children to school at the school. The subjects were also asked several questions about market problem, especially how the 
management of the school market. The following table 6 will summarize the problems of schools, especially school market management.

Table 6. Market problems (school market management)

\begin{tabular}{|c|c|}
\hline Participant & FOLDR Educational Problems Obtained \\
\hline Papua & $\begin{array}{l}\text { Management for the promotion of school citizenship is still lacking. This is due to the low interest of } \\
\text { parents to send their children to school because of the family's economic condition and they just prefer } \\
\text { the kids to work. }\end{array}$ \\
\hline $\begin{array}{l}\text { Southeast } \\
\text { Sulawesi }\end{array}$ & $\begin{array}{l}\text { Management of student interest in schools is done by helping students who live in class and are old } \\
\text { enough to continue to rise at the class level. The teacher also helps students who drop out of school to } \\
\text { take school exams. }\end{array}$ \\
\hline $\begin{array}{c}\text { West } \\
\text { Sulawesi }\end{array}$ & $\begin{array}{l}\text { Management of student interest in schools is done by helping students who live in class and are old } \\
\text { enough to continue to rise at the class level. The teacher also helps students who drop out of school to } \\
\text { take school exams. }\end{array}$ \\
\hline $\begin{array}{l}\text { East Nusa } \\
\text { Tenggara }\end{array}$ & $\begin{array}{l}\text { At the place where the subject has been in charge, the management of school promotion to community } \\
\text { members is quite good. }\end{array}$ \\
\hline $\begin{array}{l}\text { West } \\
\text { alimanta }\end{array}$ & $\begin{array}{l}\text { The management of school promotion in order to attract interest in school has been carried out when } \\
\text { there are meetings in the village customary hall and at the time of the new school year entering school. }\end{array}$ \\
\hline Maluku & $\begin{array}{l}\text { In the place where the subject has been in charge related to school promotion to attract the interest of } \\
\text { the community so that their children are admitted to the school, it is rarely done because this school is } \\
\text { the only school in the nearest village. }\end{array}$ \\
\hline $\begin{array}{l}\text { North } \\
\text { Sumatra }\end{array}$ & $\begin{array}{l}\text { The program for socialization in the introduction of schools to the community where the subject teaches } \\
\text { has been conducted at the beginning of the new school year. This is to attract the interest of children to } \\
\text { go to school. Most students come from neighboring villages, which are about } 4 \text { kilometers away. }\end{array}$ \\
\hline
\end{tabular}

Based on students who have taken TPE program and joined FOLDR teaching program, their perception about the management of school market shown in Table 6, it is clearly seen that all the elementary school teachers in seven regions state that the management of school promotion to community members is quite good. For example, the management of school promotion in order to attract interest in school has been carried out when there are meetings in the village customary hall. Meanwhile, management of student interest in schools is done by helping students who live in class and are old enough to continue to rise at the class level. The teacher also helps students who drop out of school to take school exams properly to take the certificate of graduation. Interestingly, the school promotion is held to attract the interest of the community so that their children are admitted to the school. But it is rarely done because this school is the only school in the nearest village.

Table 7 presents data from the TPE students' perception about management of learning time problems in FOLDR.

Table 7. Minute problems (management of learning times)

\begin{tabular}{cl}
\hline Participant & \multicolumn{1}{c}{ FOLDR Educational Problems Obtained } \\
\hline Papua & $\begin{array}{l}\text { Students often come with their parents to the forest and help the parents to work so } \\
\text { they often don't attend school. The school's daily life is only handled by the Principal } \\
\text { and the FOLDR teacher. This is because the teacher is absent due to the difficulty of } \\
\text { access to the trip. Management of learning hours is less effective because many } \\
\text { Southeast } \\
\text { Sulawesi }\end{array} \quad \begin{array}{l}\text { Students after school are helping parents gardening or helping parents with the } \\
\text { housework. If it has entered the harvest season of chocolate, pepper, or coconut, many } \\
\text { students who go to help harvesting the crops will go into the garden for several days } \\
\text { due to the distance of the house to the garden that is quite far. So that many students } \\
\text { do not go to school to support the family economy. When the market day arrives } \\
\text { which is only once a week, students will join their parents to trade or shop at the } \\
\text { market or maybe they will be home to take care of their younger siblings. }\end{array}$ \\
\hline
\end{tabular}


Table 7. Minute problems (management of learning times) (Continued)

\begin{tabular}{cl}
\hline Participant & \multicolumn{1}{c}{ FOLDR Educational Problems Obtained } \\
\hline West Sulawesi & $\begin{array}{l}\text { Students have lacked the motivation to study and they also often skip school and } \\
\text { attach importance to help their parents work in the garden, students often do not } \\
\text { bring stationery to school. This affects the management of study time. }\end{array}$ \\
East Nusa & $\begin{array}{l}\text { The learning environment is still less supportive of being able to display education in } \\
\text { Tenggara }\end{array}$ \\
the FOLDR area comprehensively where the subjects are assigned and this affects the \\
management of students' learning time at schools.
\end{tabular}

Based on Table 7 about their perception about the time management, it is clearly seen that all school from the seven regions have minute problems specifically in the management of learning time. First, several teachers are absent because of the difficult access to go to the school. Second, many students do not go to school to support the family economy. Third, problem is the learning environment was still less supportive of being able to display education in the FOLDR area. The other problem is management of study time in the FOLDR area is influenced by the local language, lack of attention, and motivation from the parents of students. Interestingly, the management of study time of one school in North Sumatra is good because the number of teachers is sufficient and the parents of students also support their children to be diligent in school without the duty to help with the work of parents in the garden.

\section{Defining Solutions to FOLDR Educational Problems}

The FOLDR program runs for one year for each students of TPE as teachers in FOLDR area. The first section mainly presents the problems of FOLDR program. This section defines the suggested solutions to overcome the various problems found. Also, several efforts to improve the implementation of FOLDR program are defined in Table 8, 9, 10, and 11.

Table 8. Mapping problems ıdentification about learning environment and resource/media

\begin{tabular}{|c|c|c|}
\hline Aspects & Identified Problems & How to Solve \\
\hline $\begin{array}{l}\text { Learning } \\
\text { Environment }\end{array}$ & $\begin{array}{l}\text { There is not yet a teacher's or } \\
\text { headmaster's room; the environment is } \\
\text { not conducive to emergency classrooms; } \\
\text { many livestock enter the school, disrupt } \\
\text { the concentration of student learning, } \\
\text { and damage the student learning } \\
\text { environment such as the field; plants in } \\
\text { the school environment are still lacking; } \\
\text { unavailability of trash bins and public } \\
\text { garbage disposal sites in the school } \\
\text { environment make the students; and } \\
\text { teachers throw garbage in any place. }\end{array}$ & $\begin{array}{l}\text { Among other things done submitting the } \\
\text { construction of a study room building to the } \\
\text { local office; building the emergency } \\
\text { classrooms; carry out the leafy planting } \\
\text { program; submitting the purchase of a } \\
\text { blackboard with BOS money; and providing } \\
\text { garbage bins, even with makeshift } \\
\text { materials (rattan woven made by parents). }\end{array}$ \\
\hline $\begin{array}{l}\text { Learning } \\
\text { Resources/ } \\
\text { Media }\end{array}$ & Learning media is not available. & $\begin{array}{l}\text { Submitting procurement of data boards to } \\
\text { school principals, holding a donation of } \\
\text { raising book, and making various simple } \\
\text { media from used items such as cardboard } \\
\text { and bottles of mineral water to support } \\
\text { learning activities. }\end{array}$ \\
\hline
\end{tabular}


Table 9. Mapping problems identification about students', teachers', and students' parents condition

\begin{tabular}{ll}
\hline \multicolumn{1}{c}{ Aspects } & \multicolumn{1}{c}{ Identified Problems } \\
\hline Students' & Students tend to be passive during \\
Condition & learning; there are still many students \\
& who don't go to school for several \\
& reasons; ability 3 M (reading, counting, \\
& and writing) students are still lacking; \\
& most students do not wear footwear; \\
& the discipline of students at school is \\
& still lacking; and students are going to \\
& school without bathing and students' \\
& nails are long and dirty.
\end{tabular}

Teachers' The number of teachers is still low; Condition most teachers have not graduated from bachelor's degree of Education; computer skills are still minimal; and teachers' violence is still common.

Conditions of Most parents of students have a Students' livelihood as farmers so parental Parents income is still low; parents' attention to school facilities is still lacking; and parents' awareness of the importance of education is still low.

\begin{abstract}
Using methods that invite students' interest and learning motivation, such as methods that smell like games; taking more points and certain approach to help children going to school and balancing their schedule of helping people; holding additional lessons for grades 3, 4, 5, and 6; additional tutoring activities are focused on improving students' numeracy skills, reading and writing; encouraging students to use a minimal mat using sandals; instilling neatly dressed habits by applying penalties for those who do not carry out; instilling morning bathing practices by applying penalties for those who do not carry out; and this punishment is to follow up the Government Planting Program so that the plants will remain fresh and grow fast.

Submitting the number of teachers to the local office; recommending the teachers to continue the study; conducting computer training for teachers in the district; and encouraging teachers to reduce violence and better punish using other educative and useful methods.

Holding meetings with parents/guardians; providing understanding to parents/guardians of students that education is very important; and parents/guardians must work together to build school progress.
\end{abstract}

Table 10. Mapping problems identification about student sociological background, local community culture, and education service policy

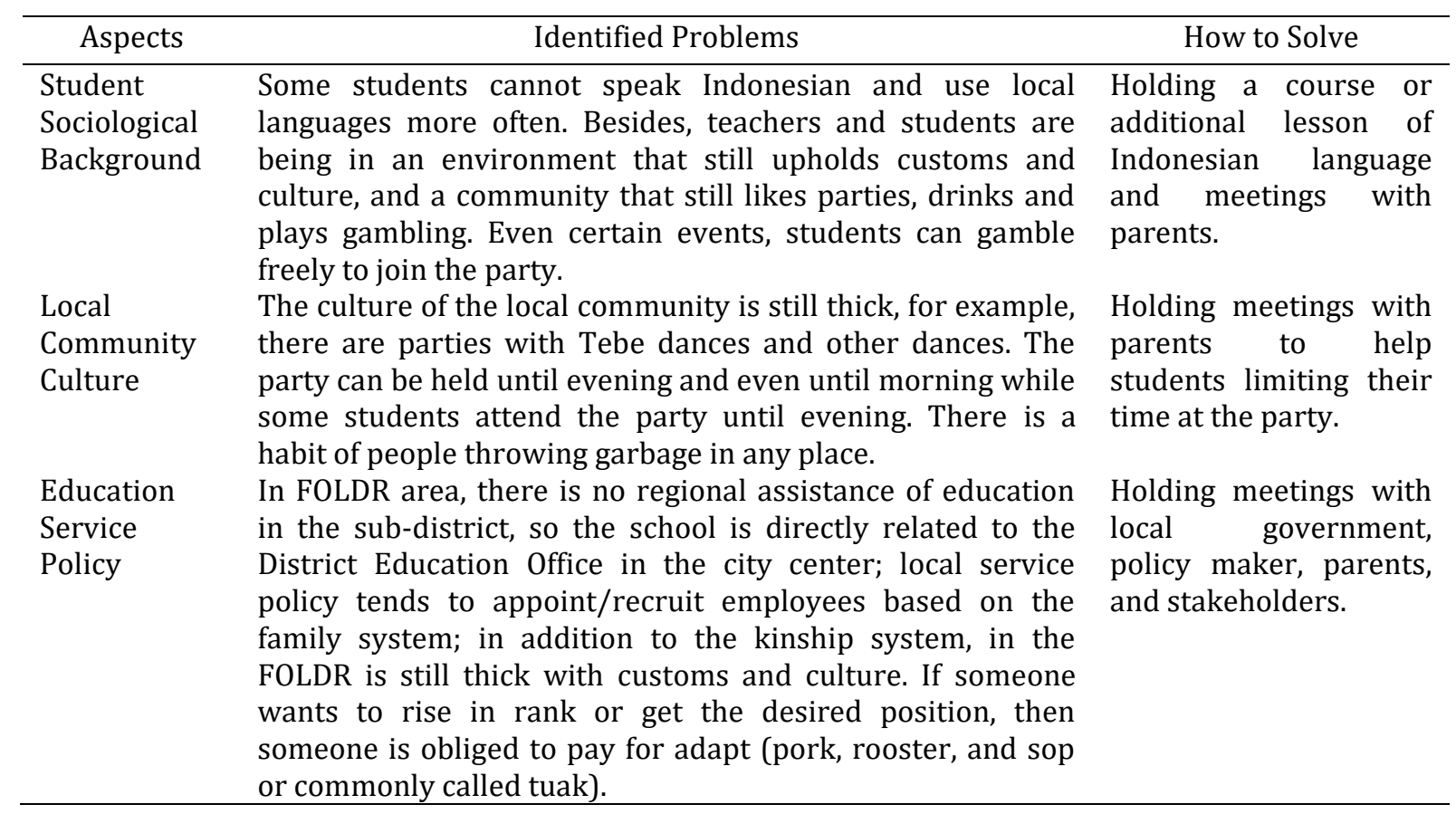


Table 11. Mapping problems Identification and solutions of teaching and learning process

\begin{tabular}{|c|c|c|c|}
\hline $\begin{array}{l}\text { Name of } \\
\text { activity }\end{array}$ & Execution time & Descriptions & Results \\
\hline $\begin{array}{l}\text { Lesson Plan } \\
\text { Training }\end{array}$ & Every chance & $\begin{array}{l}\text { Performed on a "one by one" basis } \\
\text { through the activities of compiling } \\
\text { lesson plan. }\end{array}$ & $\begin{array}{l}\text { Lesson plan is done and } \\
\text { compiled. }\end{array}$ \\
\hline $\begin{array}{l}\text { Renewal of } \\
\text { Teaching } \\
\text { Strategies }\end{array}$ & $\begin{array}{l}\text { During the } \\
\text { teaching-learning } \\
\text { process }\end{array}$ & $\begin{array}{l}\text { The use of effective learning } \\
\text { methods that are tailored to the } \\
\text { environment, the conditions of } \\
\text { students, and varied learning } \\
\text { locations. }\end{array}$ & $\begin{array}{l}\text { Student's motivation to } \\
\text { study is increasing and } \\
\text { students are more likely to } \\
\text { not skip the class. }\end{array}$ \\
\hline $\begin{array}{l}\text { Innovative } \\
\text { Learning } \\
\text { Media }\end{array}$ & $\begin{array}{l}\text { During the } \\
\text { teaching-learning } \\
\text { process }\end{array}$ & $\begin{array}{l}\text { The development of learning } \\
\text { media that are around the student } \\
\text { environment is tried to compile } \\
\text { and the use of learning media that } \\
\text { are already available in schools } \\
\text { are not utilized properly. }\end{array}$ & $\begin{array}{l}\text { Students' interest in learning } \\
\text { is increasing: learning } \\
\text { achievement increases, } \\
\text { teachers and students are } \\
\text { more communicative, and } \\
\text { learning media is used as it } \\
\text { should be. }\end{array}$ \\
\hline $\begin{array}{l}\text { Quality } \\
\text { Improve- } \\
\text { ment } \\
\text { Assessment }\end{array}$ & $\begin{array}{l}\text { Mid and end of the } \\
\text { academic year of } \\
\text { learning }\end{array}$ & $\begin{array}{l}\text { Formulation of minimum } \\
\text { completeness criteria values with } \\
\text { teachers and principals is needed; } \\
\text { the test semester will be held on } \\
\text { mid and end year implementation; } \\
\text { Additional Learning (AL) } \\
\text { Implementation is needed; } \\
\text { implementation of National } \\
\text { Examination is needed; and } \\
\text { implementation of competence } \\
\text { grade test is held. }\end{array}$ & $\begin{array}{l}\text { There are minimum } \\
\text { completeness criteria } \\
\text { values; examination results } \\
\text { exceed the minimum } \\
\text { completeness criteria; and } \\
\text { program testing are well } \\
\text { planned. }\end{array}$ \\
\hline $\begin{array}{l}\text { Develop- } \\
\text { ment of } \\
\text { Extracurri- } \\
\quad \text { cular } \\
\text { Activities }\end{array}$ & $\begin{array}{l}\text { Mid-year academic } \\
\text { year of learning }\end{array}$ & $\begin{array}{l}\text { Healthy Friday Gymnastics } \\
\text { routines are carried out by } \\
\text { students and teachers; the } \\
\text { activities of routine ceremonies } \\
\text { are conducted alternately } \\
\text { between elementary and middle } \\
\text { school students; and the habit of } \\
\text { speaking Indonesian is needed to } \\
\text { carry. }\end{array}$ & $\begin{array}{l}\text { The extracurricular is } \\
\text { accustomed by doing } \\
\text { gymnastics; skilled students } \\
\text { are placed as ceremonial } \\
\text { officers; and students begin } \\
\text { to get used to speaking } \\
\text { Indonesian and grow self- } \\
\text { confidence. }\end{array}$ \\
\hline $\begin{array}{l}\text { Develop- } \\
\text { ment of } \\
\text { Extracurri- } \\
\text { cular } \\
\text { Activities }\end{array}$ & Once a week & $\begin{array}{l}\text { Scout activities are carried out by } \\
\text { students with teacher guidance } \\
\text { and activities to cultivate } \\
\text { traditional Javanese and Nias } \\
\text { games among students is needed. }\end{array}$ & $\begin{array}{l}\text { The increasing of students' } \\
\text { discipline and character } \\
\text { development, and the } \\
\text { existence of Javanese } \\
\text { Traditional Games Festival } \\
\text { activities. }\end{array}$ \\
\hline
\end{tabular}

\section{The Impacts of the FOLDR Program on FOLDR Regional Education}

First, the section explains the impact of FOLDR program in Papua. The implementation of FOLDR program in Papua has a positive impact on the area. The presence of three-year high school teachers can meet the vacancies of teachers and lack of teachers who have good educational qualifications. Those who were in schools lacking teachers can be helped. What was previously a school that didn't work should have been able to do well.

Second, the impact of FOLDR program in Central Sulawesi is defined. FOLDR program has a very good impact to both the educational aspect and also cultural aspect, especially in the progress of schools, the role of FOLDR with program activities in schools, communities, subdistricts, and the district themselves. The great benefits are particularly felt by the school and the community of Baina'a. Many FOLDR teachers help schools in the education administration, 
making school budget activities plans and even accountability for OAF funds reports. In the subjects' opinion, the existence of FOLDR has had an impact on education in the FOLDR area. This can be seen from the adequate acceptance from the education office, teachers, and the surrounding community. The FOLDR program has a positive influence on the surrounding community. The existence of FOLDR program can at least provide inspiration and examples for local teachers in innovating during the learning process. FOLDR teachers, with all the knowledge brought, can share knowledge and experience in all matters related to learning process in rural area of Indonesia as it leads to the balancing national education.

Third, the impact of FOLDR program in West Sulawesi is good. It is felt real by residents in the FOLDR area. The FOLDR participants are well received by the community because their presence is felt by the community itself that the FOLDR participants have at least a positive influence on education at FOLDR. The FOLDR participants not only acted as complementary or substitute teachers in the FOLDR area but they also became motivators and drivers so that education in the FOLDR area could progress and develop in a better direction.

Fourth, the impact of FOLDR program in East Nusa Tenggara is also reportedly good. The existence of FOLDR teachers in the FOLDR area, especially in Insana sub district, North Central Timor Regency, East Nusa Tenggara Province, has quite an impact on the development of education activities there. The FOLDR teachers are always involved in various educational activities in Insana district. The FOLDR teachers also play a role in activities in the community. We FOLDR teachers are given more trust by teachers in schools or service agencies in Insana sub district. In some activities, such as competitions, teacher work groups, scout activities, and the implementation of educational holidays FOLDR teachers actively participate in these activities. Even in the school environment, the 3-year high school teacher is believed to be a classroom teacher for one year of service and given the opportunity to implement proposed activities and programs for serving schools in the area for school staff and citizen.

The FOLDR program in West Kalimantan greatly impacts the local area. The reason is that in the FOLDR area there is still a shortage of educators and many educators whose educational qualifications are not suitable. The existence of FOLDR is very helpful for advancing education so there are some new things developed in the FOLDR program. Students are also very enthusiastic about learning with the arrival of the FOLDR teachers in their schools.

The impact of FOLDR program in Maluku greatly impacts Education in the FOLDR area. There are many changes, especially in schools, starting from the completeness of school administration curriculum documents and classes, media and learning methods. This provides an experience not only for the FOLDR participants themselves but also for students, teachers, parents of students, and the community. Little or a lot of the existence of FOLDR contributes to the impact on the education sector in placement. This can be seen from various activities that have been carried out in an effort to advance the field of education.

In this case, the FOLDR participants in Kilmasa village introduced school education to IT skills, both offline and online. FOLDR participants invite teachers to get to know how to use a laptop properly and utilize its maximum usage in learning. Teachers may make anything using a laptop, starting from class administration, media, calendar, documentation of class activities, creating test, and so on. In addition to teaching at the school, the 3-year high school teacher is also an instructor in the community to open up people's insights into the importance of education.

The impact of FOLDR program in Nias, North Sumatra, helps and has an impact on education equity, especially the lack of qualified teachers who are in accordance with their fields in the FOLDR area. In general, the community is all very happy with the arrival of the SM$3 \mathrm{~T}$ teacher with a different version of the response. Even in daily activities of behavior, speech influences the existence of better changes in society. The impact that will be felt on the existence of FOLDR makes students eager for school because in daily learning activities various methods and learning media are used. The existence of the FOLDR program provides constructive changes for the FOLDR regions, especially Nias Island. 


\section{DISCUSSION and CONCLUSIONS}

This section discusses about the results defined in the previous section. The problem of education for FOLDR regions is referred to $7 \mathrm{M}$ of management characteristics from seven regions in rural area of Indonesia. The findings reveal some problems. First, man problem covers human resources in schools, such the principal, teachers, students, and parents of students, its problems are quantity, quality, competency, and human resources development. Second, the money problem discusses school management and education funding. In this section, there are no problems because school funding is free for students and the existence of school operational assistance funds or OAF as capital resource in school funding. OAF covers school operational finance to support the providing of school administration and school facilities (Kathy et al., 2019). Third, methods problem discusses learning methods and innovations in teaching-learning process, because the lack of teacher competency there has an impact on the lack of development of learning methods and innovations. For example, the teachers still use conventional methods, lectures, memorization, and dictation.

Learning methods are very important for learning process. In the learning process, the teacher is a change agent who has a strategic key position in creating conducive learning environment and involves students in learning. For this reason, education practitioners are required to be capable and skilled in playing a number of roles simultaneously (Maba, 2017). As an agent of change, a teacher has a dominant role and determinant of the success of the learning process. The main determining factor is communication. In learning process, the communication process is influenced by internal and external factors. Some of these factors are varied such as psychological barriers: interests, talents, attitudes, intelligence, knowledge, and motivation (Maba, 2017). As a strategic central figure, a teacher must be able to choose and manage various strategies, methods, and learning techniques that can support active, creative, productive, and efficient learning (Kemp \& Dauton, 1985). Several other studies also revealed that the presence of technology and innovative learning methods can have a good effect on student learning outcomes (Aniello, 2012; Barhoumi, 2015).

Fourth, machine problem discusses technology and learning media, the lack of facilities that support the process of teaching and learning activities, there is no electricity and internet signal. The location is also far from the city. Various cases lead to the problems that the media of learning are not available. So that it causes the use of learning media that is still quite low. The availability of instructional media is very influential for learning (Breen, 2015). Moreover, the lack of electricity, this will definitely interfere with student activities in learning. The results of the study provide data that learning media and the availability of other learning facilities have a positive effect in developing the quality of learning in the classroom. Especially if it is accompanied by the use of innovative learning models (Barber et al., 2015).

Fifth, the material problem discusses material and sum learns. The material used is only teacher knowledge and makeshift textbooks, because of the limited facilities and unavailable infrastructure. According to Richards and Rodgers, some things such as syllabus, training and good classroom activities will support the achievement of teaching objectives (Bagus et al., 2017). All teaching materials, exercises, assignments and learning activities must be well designed so as to allow interaction and communication during the teaching and learning process between students (Aslan, 2015; Beavers et al., 2015; Bethard et al., 2012). In designing this, the teacher needs to consider the differences between students in various ways, such as communication needs, motivation, and attitudes (Littlewood, 1986). Furthermore, Littlewood explained that teaching materials, exercises, and communicative activities must be in accordance with students' needs. This is certainly a specific goal has implications for the selection of teaching materials that must be adjusted to the needs of students. In addition, syllabus packaging, exercises, activities must also be interesting and fun so that it can increase motivation and change students' attitudes (Granger, 2012; Lievens \& Sacket, 2012).

Sixth, market problem discusses school marketing strategies; there is no problem about the promotion of school. The program for socialization in the introduction of schools to the community has conducted at the beginning of the new school year. Seventh, minute's problem 
discusses the management of study time. From all school in this area, they have minute's problems specifically in the management of learning time. The problems are some of the teachers were absent, many students did not go to school to support the family economy, and the learning environment was still less supportive. The local language forbade and limited the lively learning using Indonesian language. The lack of attention and motivation from the parents of students also causes the problems in students to attend the class properly. All of the problems defined in the previous section have influenced time management of learning in the schools.

Teaching reflective skills in the academic world has become increasingly important, as is managing time (Rampullo et al., 2015). The teacher must have good documentation regarding his journey in teaching, whether it is made in a diary, report, or portfolio. This kind of activity has long been carried out by several universities in the UK. Teaching reflective skills began to emerge throughout the curriculum, with many different types of students being asked to compile reflective essays, reports, journals, logs, diaries, or portfolios as part of their assignments at UK universities (Helyer \& Kay, 2015). Assistance with this reflection is often found in student handbooks, as part of successful induction days and contains theories and learning styles, metacognition, and student self-analysis (Helyer \& Price, 2015).

To sum up, this research has several findings. First, regarding the problem of FOLDR area in seven regions, it is revealed that the problem of education for frontier, outermost, and least developed regions refers to 7 M (Man, Money, Methods, Machine, Material, Market, Minutes), from seven regions have some problems about the implementation education referred to $7 \mathrm{M}$. Second, the FOLDR program runs for one year, there are the various problems found and several efforts to improve it. The solution of the problem in FOLDR such as submitting the construction of a study room building to the local office, hold a donation raising book for both textbooks and reading books for students, making various simple media, using methods that invite students' interest and learning motivation, hold additional lessons, submitting the number of teacher to the local office, hold computer training for teachers, and the others solution. Third, the impact of FOLDR program, it has a positive impact on the FOLDR area, especially in the progress of schools, the role of FOLDR with program activities in schools, communities, sub-districts, and districts. Researchers provide the following recommendations:

1. It is recommended that the FOLDR program remains existed and sustainable. For example, when a student is graduating from educational bachelor's degree, it is better that they are immediately placed in the FOLDR area to later get the title of professional teacher.

2. Judging from the supervision system, there is a need for improvements to be more attentive so that people can assess not only the area with easily found location and the access to the place is easier (vehicle can be passed). It will need to be preserved at least one in every sub district because each region has different problems and different handling methods are also different. In addition, accurate coordination is needed in determining target areas for FOLDR area so the goal of making a better nationals educational achievement can be gained.

3. The government should focus on the education budget in the FOLDR area, namely by giving more funds to the area. The focused budget is expected to help completing the facilities, repairing the facilities, and providing the infrastructure needed by the FOLDR area.

4. The government should pay more attention to teachers who teach in the FOLDR area, especially related to health, welfare, and security. Educators assigned to FOLDR are given life and health insurance to have a comfortable and safe feeling guarantee while on duty.

\section{REFERENCES}

Altinyelken, H. K. (2011). Student-centered pedagogy in Turkey: Conceptualizations, interpretations and $\begin{array}{lllll}\text { practices. Journal of Education } & \text { 137-160. }\end{array}$ https://doi.org/10.1080/02680939.2010.504886

Aniello. (2012). Virtual laboratory for physics teaching and learning. IEEE Trans. Magn. Journal, 58(1), 2125.

Aslan, S. (2015). Is learning by teaching effective in gaining $21^{\text {st }}$ century skills? The views of pre-service science teachers. Educational Sciences: Theory \& Practice, 15(6), 1441-1457. 
Bagus, I., Mantra, N., Ayu, I., Sri, M., \& Author, C. (2017). Developing learning methods of Indonesian as a foreign language. International Journal of Social Sciences and Humanities, 1(2), 51-57. https://doi.org/10.21744/ijssh.v1i2.41

Barber, W., King, S., \& Buchanan, S. (2015). Problem based learning and authentic assessment in digital pedagogy : Embracing the role of collaborative communities. The Electronic Journal of E-Learning, 13(2), 59-67.

Barhoumi, C. (2015). The Effectiveness of whatsapp mobile learning activities guided by activity theory on students' knowledge management. Contemporary Educational Technology, 6(3), 221-238.

Beavers, A. S., Lounsbury, J. W., Richards, J. K., Huck, S. W., Skolits, G. J. \& Esquivel, S. L. (2013). Practical considerations for using exploratory factor analysis in educational research. Practical Assessment, Research \& Evaluation, 18(6), 1-13.

Beck, F. D. \& Shoffstall, G. W. (2005). How do rural schools fare under high stake testing regime?. Journal of Research in Rural Education, 20, 1-12.

Bethard, S., Hang, H., Okoye, I., Martin, J. H., Sultan, M. A., \& Summer, T. (2012). Identifying science concepts and student misconceptions in an interactive essay writing tutor. Proceedings of the Seventh Workshop on Building Educational Applications Using NLP, 12, 12-21.

Breen, M. (2015). Virtual laboratory of alternating current circuit subjects for students. Science Journal, $32(1), 5-15$.

Buchory, S. (2012). Key teacher of national education. Yogyakarta: Leotikaprio.

Campbell, A. M. \& Yates, G. C. R. (2011). Want to be a country teacher? No, I am too Metrocentric. Journal of Research in Rural Education, 26, 1-12.

Cochran-Smith, M., Shakman, K., Jong, C., Terrell, D.G., Barnatt, J., \& McQuillan, P. (2009). Good and just teaching: The case of social justice in teacher education. American Journal of Education, 115 (3), 347-377.

Cuervo, H. (2012). Enlarging the social justice agenda in education: An analysis of rural teachers' narratives beyond the distributive dimension. Asia Pasific Journal of Teacher Education, 40(2), 8395.

Fitzgerald, J. \& Lenhart, J. (2015). Eco-districts: Can they accelerate urban climate planning? Environment and Planning C. Government and Policy, 00, 1-17. https://doi.org/10.1177/0263774X15614666

Flora, C. B., Flora, J. L., \& Fey, S. (2003). Rural communities: Legacy and change (2nd Ed.). Westview Press, Boulder.

Goodwin, A. L. \& Kosnik, C. (2013). Quality teacher educator's quality teachers? Conceptualizing essential domain of knowledge for those who teach teachers. Teacher Development, 17 (3), 334-346.

Granger, E. M. (2012). The efficacy of student-centered instruction in supporting science learning. Journal for Research in Physics Education, 338(1126), 105-108.

Green, B. (2015). Australian education and rural-regional sustainability. Australian and International Journal of Rural Education, 25, 145-151.

Hakhverdian, A., Van Elsas, E., Van Der Brug, W., \& Kuhn, T. (2013). Euroscepticism and education: A longitudinal study of 12 EU member states, 1973-2010. European Union Politics, 14(4), 522541. https://doi.org/10.1177/1465116513489779

Halsey, J. (2011). Farm fair voices, space, history, the middle ground and the future of rural communities. Education in Rural Australia, 21(1), 39-66.

Helyer, R. \& Kay, J. (2015). "Building capabilities for your future”, in Helyer, R. (Ed.). The Work-Based Learning Student Handbook, 2nd ed., Palgrave, London, pp. 31-50.

Helyer, R. \& Price, A. (2015). “Developing the whole person”, in Helyer, R. (Ed.). Facilitating Work-Based Learning: A Tutor Handbook, Palgrave, London.

Kathy, E., Baidawi, S., Dowse, L., \& Smith, L. (2019). Services to young people with complex support needs in rural and regional Australia: Beyond a metro-centric response. Children and Youth Services Review, 99, 97-106. https://doi.org/10.1016/j.childyouth.2019.01.033

Karaomerlioglu, M. A. (1998). The village institutes experience in Turkey. British Journal of Middle Eastern Studies, 25(1), 47-73.

Kemp, J. E. \& Dauton, D. K. 1985. Planning and producing Instructional media (Fifth Edition). New York: Herper \& Row Publishers.

Lievens, F. \& Sackett, P. R. (2012). The validity of interpersonal skills assessment via situational judgment tests for predicting academic success and job performance. Journal of Applied Psychology, 97(2), 460-468.

Littlewood, W. T. (1986). Learning Foreign and Second Language. London: Cambridge University Press. 
Maba, W. (2017). Teachers' perception on the implementation of the assessment process in 2013 curriculum. International Journal of Social Sciences and Humanities, 1(2), 1-9. https://doi.org/http://dx.doi.org/10.21744/ijssh.v1i2.26

McManus, P., Walmsley, J., Argent, N., Baum, S. (2012). Rural community and rural resilience: What is important to farmers in keeping their country towns alive?. Journal of Rural Studies, 28(1), 20-29.

Mulkeen, A. \& Chen, D (Eds). (2008). Teachers for rural schools, experiences in Lesotho, Malawi, Mozambique, Tanzania, And Uganda. The World Bank: Washington, D.C.

Nagy, J. \& Robinson, S. R. (2013). Quality control barriers in adapting 'metro-centric' education to regional needs [online]. Australian and International Journal of Rural Education, 23(1), 75-90.

OECD. (2015). Program for international student assessment (PISA) Resul from PISA 2015. Retrieved from https://www.oecd.org/pisa/PISA-2015-Indonesia.pdf

Rampullo, A., Licciardello, O., \& Castiglione, C. (2015). Intrapersonal factors effects on professional orientation and environmental representations. Procedia Social and Behavioral Sciences, 205, 422-428.

Reeves, E. B. \& Bylund, R. A. (2005). Are rural schools inferior to urban schools? A multilevel analysis of school accountability trends in Kentucky. Rural Sociology, 70, 360-386.

Singh, P., Rahman, A. A., \& Hoon, T. S. (2010). Languages and mathematics achievements among rural and urban primary four pupils: a Malaysian experience. Journal of Science and Mathematics Education in Southeast Asia, 33, 65-85.

Sugiyono. (2013). Educational research methods: quantitative, qualitative and $R \&$ D approaches. Bandung: Alfabeta.

Yustina., D. \& Dahnilsyah. (2015). The creativity of FOLDR participants at Riau University in developing knowledge using project-based learning at Lany Jaya, Papua, Indonesia. Australian Journal of Basic and Applied Sciences, 9(31), 530-536. 